\title{
Reducing Pain Score using Finger Hold Technique on Patient with Mild Head Injury in Emergency Department (of) General Hospital Brigadier H Hasan Basry Kandangan 2018
}

\author{
Budiya Rahman, Noor Khalilati \\ Universitas Muhammadiyah Banjarmasin, South Kalimantan, Indonesia \\ Corresponding author: budiprivate@gmail.com
}

\begin{abstract}
Background: Treatment for patients who have mild head injury are mostly pharmacological. (Despite of what happens to the patients so far, they do not have to be given drugs as treatment, they can be treated in other ways, that is not in the form of drugs) Purpose: To determine effect of the finger hold technique on decreasing the scale of acute pain on patients with mild head injury.

Method: This research used Quasy Experimental design with the One Group PretestPostest Design. The population of Mild Head Injury patients in the first semester of 2018 in November-December were 20 people. Samples taken by Accidental Sampling technique in 20 respondents. Instrument for this reseach used the questionnaire sheet. Measurement of respondent's pain level using NRS rating scale 0-10 and the data analyzed using univariate analysis and bivariate analysis with Paired T-Test.
\end{abstract}

Results: The scale of pain before the finger hold technique on mild head injury patients mostly got moderate pain on 15 people $(75 \%)$. The scale of pain after the finger hold technique was performed, head injury patients mostly got mild pain category on 13 people $(65 \%)$. The hypothesis is accepted with a significance level of $0.000<0.05$.

Conclusion: By giving finger hold technique, it can decrease pain level patients with mild head injury

Keywords: Finger Hold Technique, Acute Pain Scale, Mild Head Injury Patient

Received: February 7, 2019; Revised : February 20, 2019; Accepted March 09, 2019

How to Cite: Rahman, B., \& Khalilati, N. (2019). Reducing Pain Score using Finger Hold Technique on Patient with Mild Head Injury in Emergency Department (of) General Hospital Brigadier H Hasan Basry Kandangan 2018. Journal Of Nursing Practice. 2(2). 102-108. https://doi.org/10.30994/jnp.v2i2.52 


\section{BACKGROUND}

Head injury is a problem for the community because it can cause death, disability, and reduce productive time, head injury has a high mortality rate, so it requires proper, fast and accurate handling. Head injuries include trauma to the scalp, skull or brain. Brain is the most valuable and vital human's organ, basically the brain is well protected by the skull, it is large, heavy, and easily injured, especially due to collisions that rapidly accelerate and decelerate within the skull's borders. Significant injury to the brain can cause a contemporary breakdown of function. But never forget that unconsciousness can also be a coma, or due to an attack from a stroke, hypoglycemia which together can cause an irreversible decrease in consciousness, when an injury occurs pain will definitely appear as a response from the body. Everyone that feels the pain will have a different way to express it based on previous perceptions of the pain, the perception will depend on the experience, knowledge, gender and age of someone who experienced the pain. Head injuries are categorized into 3 based on the value of the Glasgow Coma Scale (GCS), there are: mild head injury (CKR) if the GCS score is 13-15, moderate head injury (CKS) with GCS 9-12, and severe head injury (CKB) with GCS $\leq 8$ (Muttaqin, 2008). Severe head injuries are divided into two types associated with causal factors, which are closed (eg due to falls, vehicle accidents, or hit by objects) and penetration (for example, gunshot and impact wounds or sharp objects) (Centers for Disease Control and Prevention, 2014).

During this time the treatment for patients who experienced mild head injuries are mostly pharmacological at the ED of General Hospital Brigadier General H Hasan Basry Kandangan. Despite of what happens to the patients so far, they do not have to be given drugs as treatment, they can be treated in other ways, that is not in the form of drugs. In addition to patients' treatment in the Emergency Room, so the researchers tried to give finger hold treatment to reduce pain on patients who are suffering from minor head injuries.

One of non-pharmacological treatment that can be done is a hand-hold relaxation technique. The technique of holding a finger is part of the Jin Shin Jyutsu technique. Jin Shin Jyutsu is Japanese acupressure. The form of art that uses a simple touch of hands and breathing to balance energy in the body and hoping the pain will be reduced. Hands (fingers and palms) are simple and powerful tools to harmonize and bring the body into balance. Each fingers are related to everyday attitudes. The thumb is associated with anxiety, the index finger is associated with fear, the middle finger is associated with anger, the ring finger is associated with sadness, and the little finger is associated with low selfesteem and discouragement (Hill, 2011).

\section{OBJECTIVE}

This research aims to determine effect of the finger hold technique on decreasing the scale of acute pain on patients with mild head injury.

\section{METHODS}

This research used Quasy Experimental design with the One Group Pretest-Postest Design approach. This research is not really a research so there are still other variables that influence the formation of dependent variables (Nursalam, 2011). This researchers conducted pain assessments in the intervention group before and after Finger hold exercise. The population in this study were all patients with mild head injury who entered the emergency department of the General Hospital Brigadier H Hasan Basry Kandangan on November $1^{\text {st }}$ - November $30^{\text {th }}$, there were 20 people. Sampling technique were using accidental sampling without inclusion and exclusion criteria. 
Data collected using the observation method. The results of the pain score are filled on the observation sheet which consists on scale of 0 (no pain), on scale of 1-3 (mild pain), on scale of 4-6 (moderate pain), on scale of 7-10 (severe pain). Then, respondents were taught the finger hold exercise technique and practiced it for 15 minutes. After that, researcher re-assess the pain score of the respondents. This research used Paired T-Test to determine the effect of the action of Finger hold training in a scale of acute pain on patients with mild head injury in the IGD Room of the General Hospital Brigadier General H Hasan Basry Kandangan.

\section{RESULT}

\section{a. Characteristics of Reponden}

Characteristic respondents of this research based on age is 45-52 years with Mild Head Injury which consist of 13 male respondents (65\%) and 7 female respondents $(35 \%)$.

\begin{tabular}{llcc}
\hline No. & Sex & $\begin{array}{c}\text { Frequency } \\
(\mathbf{f})\end{array}$ & $\begin{array}{c}\text { Prosentase } \\
(\mathbf{\%})\end{array}$ \\
\hline 1. & Men & 13 & 65 \\
\hline 2. & Women & 7 & 35 \\
\hline & Total & 20 & 100 \\
\hline
\end{tabular}

Table. 1 Frequency Distribution of Sex

\section{b. Univariate Results}

\begin{tabular}{llcc}
\hline No. & Pain Score Before Finger Hold Therapy & $\begin{array}{c}\text { Frequency } \\
\text { (f) }\end{array}$ & $\begin{array}{c}\text { Prosentase } \\
(\boldsymbol{\%})\end{array}$ \\
\hline 1. & Moderate pain & 13 & 65.0 \\
\hline 2. & Mild pain & 7 & 35.0 \\
\hline & Total & 20 & 100.0 \\
\hline
\end{tabular}

(Source: Data on Respondents' Observation Results in 2018)

Table. 2 Frequency Distribution Before Given Finger Hold Therapy

The results showed that the scale of pain before the therapy was given mostly felt moderate pain with 13 people $(65 \%)$ and felt the mild pain only 7 people $(35 \%)$. This is due to the lack of joint movement in their hands while the hand is one of the central requirements that can stimulate the human brain, especially on patients who have a head injury. The level of pain after the finger hold technique has given to mild head injury patients in the Emergency Room of the General Hospital of Brigadier General Hasan Basry Kandangan in 2018. The results of the study on the scale of pain after Finger Hold therapy can be seen as follows: 
No. Pain Score After Finger Hold Therapy

Frequency Prosentase

\begin{tabular}{llcc}
\hline 1. & Mild pain & 13 & 65.0 \\
\hline 2. & No pain & 7 & 35.0 \\
\hline & Total & 20 & 100.0
\end{tabular}

(Source: Data on Respondents' Observation Results in 2018)

Table. 3 Frequency Distribution After Given Finger Hold Therapy

The results showed that the scale of pain after the therapy was given mostly felt mild pain with 13 people $(65 \%)$ and felt the moderate pain only 7 people $(35 \%)$. Patients who feel pain are less because they feel a lot of mild pain after being given a Finger Hold. This means that the therapy has succeded. Based on these results, it showed that after being given Finger Hold therapy there was a decrease in the results, patients began to feel mild pain and not feel severe pain and only a few still feel moderate pain. It all because they feel comfortable and can withstand their pain when given the therapy.

\section{c. Bivariate Results}

\begin{tabular}{lccc}
\hline Treatmen of finger hold & Mean (C) & SD & Uji Paired T-Test P Value \\
\hline Before (Pretest) treatment & 3,50 & 1,50 & \multirow{2}{*}{0,000} \\
\hline After (Posttest) treatment & 1,45 & 1,19 & \\
\hline
\end{tabular}

Table. 4 Paired T-Test Analysis

The level of differences of the Mean Difference value (difference in mean values) before being given the Finger Hold technique their results reached 3.50 and after being given the brainstorming method it decreased to 1.4. It means that there was a decrease in their pain level from the comparison of the numbers which is 2.15 . Meanwhile from the results of the T-test, it is known that the results of the significant level after given the brainstorming method are Sig. (2-tailed) shows that there is a strong influence before and after the method of brainstorming was given, which is $0.000<0.05$, means that it can be concluded based on the test that Ha accepted, there is an effect of finger hold technique on decreasing the scale of acute pain on mild head injury patients in emergency room installation RSUD Brigadier General $\mathrm{H}$ Hasan Basry Kandangan. The early results of the patient who felt a moderate pain became a mild pain and patients who felt mild pain became painless after being treated with finger hold when they were in the emergency room with the head injury. The results of the Paired T-Test to see the difference between before and after treatment. The results for this study on the effect of Finger Hold exercise measures on the scale of acute pain on patients with mild head injury in the IGD Room of the General Hospital, Brigadier General H Hasan Basry Kandangan. The results of this study are Paired T-Test Test obtained $\mathrm{P}$ value is $0.000<0.05$, then $\mathrm{H}_{0}$ is rejected and $\mathrm{H}_{1}$ is accepted.

\section{DISCUSSION}

Effect of the finger hold technique to decrease the scale of acute pain on mild head injury patients in Emergency Department of General Brigadier H Hasan Basry Kandangan Hospital in 2018. Based on the results of the study showed that there was an effect of the finger hold technique on the scale of acute pain on patients with mild head injury with a 
difference value of 2.05> 1.96 and it supported by the results of a significant level of 0,000 $<0.05$. This can be seen by the results of the technique that have been given during the process of the research which has been carried out with the finger hold technique can reduce the pain of patients who are experiencing head injuries.

Same results of the research by Natalia et.al (2017), about finger hold relaxation therapy for the reduction of joint pain in the elderly in RW 1 and 2 in the urban ward of Kediri city. The results showed that there was difference in the scale of pain before and after finger hand relaxation technique. Another research by Astutik and Kurlinawati (2017), about finger handhold relaxation therapy for reduction pain in post sectio caesarean patients in the pomegranate room at Kertosono Hospital.

Relaxation is an action to relax skeletal muscles which is believed to reduce pain by relaxing muscle tension that supports pain (Zeez, 2012). Finger holding relaxation technique is a relaxation technique with fingers and energy flow in the body (Liana, 2008). Hand-hold relaxation produces impulses which is sent through non-nociceptive afferent nerve fibers. Nonnociceptor nerve fibers cause the "gate" closed so the stimulus to the cerebral cortex is inhibited or reduced due to counter stimulation of relaxation and holding of the finger. It will make the intensity of the pain will change or experience modulation due to stimulation of finger holding relaxation that is earlier and more reaches the brain (Pinandita, 2012).

Pain is an unpleasant emotional and sensory experience that came up from actual tissue damage or shows damage (Maryunani, 2010). Prasetyo (2010) explains that acute pain is short duration (approximately 6 months) and will disappear without treatment after the damaged area has recovered. Nurses have a role in overcoming various nursing problems experienced by patients, especially pain nursing problems.

This research was also reinforced by Andika \& Mustafa (2016) who studied the Effect of Hand-hold Relaxation Technique on the Reduction of Pain Intensity in Post Patients with Surgery Appendictomy which has found that finger hand-hold relaxation technique help reduce the pain and produce relaxation and smoothen the circulation. This research is reinforced by other research by Karokaro M (2014) which examined the effect of finger-hold relaxation technique on decreasing pain intensity.

Hand hold relaxation can control and restore emotions that will make the body relax. The presence of stimulation in the surgical wound causes the release of pain mediators which will stimulate impulse transmission along the nociceptive afferent fibers to the gelatinose substance (gate) in the spinal cord to pass through the thalamus and then convey to the cerebral cortex and interpreted as pain (Pinandita, 2012). Sofiyah's (2014) study about the effect of finger handhold relaxation technique on changes pain scale on patients with sectio caesarean surgery, the results showed of a $p$ value of 0.000 , there was a significant difference in the scale of pain after being given finger handhold relaxation technique between the experimental group and the control group.

Hand-hold relaxation produces impulses that are sent through non-nociceptive afferent nerve fibers as a counter stimulation of pain in the cerebral cortex, causing pain intensity change or undergo modulation due to stimulation of finger holding relaxation who came first and more reaching the brain (Pinandita, Purwanti \& Utoyo, 2012). Handhold relaxation, or also as known as finger hold, is a relaxation technique that used to relieve or reduce pain intensity. Finger hand-hold relaxation therapy as a pharmacological therapy companion that aims to increase the analgesic effect as a pain relieve therapy.

Based on the results of these study, it can be concluded that the presence of finger hold technique has an effect on decreasing the scale of acute pain on patients with mild 
head injury in Emergency Installation of RSUD Brigadier H Hasan Basry Kandangan in 2018, this means by this way can reduce pain on patients who suffered head injuries. It has seen from the finger hold technique that has been carried out on patients at Hasan Basry Hospital Kandangan where respondents feel if the pain in the head still can be restrained and does not disturb the pattern of activity, its still tolerable (pain is felt) such as being punch in the face or injected.

Actually, by the existence of this Finger Hold technique can provide relaxation and also distraction on patients who suffer from mild head injury because the focus of their activity moves eventually on their hands and makes them more concentrated in the hand pain, besides the hands the pain is also distracted with the guidance breathing by the researcher. Gripping your thumb with your palms can give an effect for patients to make them not feeling any excessive worry and make them relex and reduce pain especially on their heads, it because their sense of mind will move to the hand. This hand hold will assign excessive fear, excessive anger, excessive sadness and excessive headaches on behind.

\section{ACKNOWLEDGMENT}

The limitation of this study is sometimes patients need to be given direction and guidance on how to do finger hold while they were on the ED and sometimes they feel embarrassed when given the treatment. Patients sometimes still feel sick and need to get rest so the researchers must wait in advance for the patient.

\section{CONCLUSION}

Basically holding a finger while taking a deep breath can reduce and cure physical and emotional tension, because the grip on the finger will warm the exit points and the entry of energy in the meredian which is located on the fingers of patients who have brain head injury, so that blockage in the path energy becomes smooth. This hand-hold technique is very helpful in everyday life. When in a difficult situation, feeling angry, tense, afraid or want to cry without cause, the fingers can be grasped to bring a sense of peace, focus and comfort so that we can deal with the situation, feeling more calm and able to make decisions.

\section{REFERENCES:}

Astutik, P., \& Kurlinawati, E. (2017). Pengaruh Relaksasi Ganggam Jari Terhadap Penurunan Nyeri pada Pasien Post Sectio Caesarea di Ruang Delima RSUD Kertosono. STRADA Jurnal Ilmiah Kesehatan, Vol. 6 No. 2 Hal. 30-37.

Center for Disease Control and Prevention. (2014). CDC growth charts. Www.cdc.gov> (Diakses tanggal 01 juni 2018).

Natalia, D, Idris, T \& Astarani, K. (2017). Terapi Relaksasi Genggam Jari Terhadap Penurunannyeri Sendi Pada Lansia. Vol 3 (1), Hal 23-32.

Hill, R. Y. (2011). Nursing from the inside-out: Living and nursing from the highest point of your consciousness. London: Jones and Barlett Publishers.

Liana, E. (2008). Teknik Relaksasi Genggam Jari untuk Keseimbangan Emosi. Http://www. Pembelajar.com/teknik relaksasi-genggam jari untuk keseimbangan emosi. <diakses tanggal 08 Juli 2018>.

Maryunani, A. (2010). Ilmu Kesehatan Anak. Jakarta: CV. Trans Info Media. 
Andika, M. \& Mustafa, R. (2016). Pengaruh Teknik Relaksasi Genggan Jari Terhadap Penurunan Intensitas Nyeri Paisen Post Operasi Apendiktomy di RS DR. Reksodiwiryo. STIKes Mercubaktijaya Padang.

Nursalam, 2008. Konsep dan Penerapan Metodologi Penelitian Ilmu Keperawatan: Jakarta: Salemba Medika.

Pinandita, I., Purwanti, E., Utoyo, B. (2012). Pengaruh Teknik Relaksasi Genggam Jari Terhadap Penurunan Intensitas Nyeri Pada Pasien Post Operasi Laparotomi. Http://digilib. Stikes muh gombong.ac.id/files/diskl/27/jtstikesmuhgo-gdl-iinpinandi13444-2-hal.32-3.pdf. <Diakses tanggal 26 Juli 2018>

Prasetyo, S. N. (2010). Konsep dan Proses Keperawatan Nyeri. Yogyakarta : Graha Ilmu

Turk, D. \& Melzack, R. (2010). Handbook of Pain Assesment. Newyork: Guilford.

Zees, R.F. (2012). Pengaruh Teknik Relaksasi terhadap Respon Adaptasi Nyeri Pada Pasien Apendiktomi di Ruang G2 Lantai II. (diakses tanggal 26 Juli 2018). 